\title{
Virus-induced Alterations in Cyclic Adenosine Monophosphate Generation in Hamster Islets of Langerhans
}

\author{
Elliot J. Rayfield and Katherine Julia Kelly \\ Diabetes Research Laboratory, Division of Arteriosclerosis and Metabolism, Department of Medicine, Mount Sinai School of Medicine,
} New York, New York 10029

\begin{abstract}
Inoculation of golden Syrian hamsters with Venezuelan encephalitis (VE) virus results in a sustained diminution in glucosestimulated insulin release that is correctable by cyclic (c) AMP analogs and phosphodiesterase inhibitors. This suggested the importance of directly measuring cAMP content in VE-infected and control islets in response to insulin secretagogues. The basal CAMP content of VE-infected islets $(0.14 \pm 0.02 \mathrm{pmol} / \mu \mathrm{g}$ islet DNA) was approximately half that of control islets $(0.27 \pm 0.02$ $\mathrm{pmol} / \mu \mathrm{g}$ islet DNA $(P<0.05)$. In the presence of $10 \mu \mathrm{M}$ glucagon (and $3 \mathrm{mM}$ glucose), the rate of cAMP generation in VEinfected islets was only half that of control islets. With $10 \mathrm{mM}$ $\alpha$-ketoisocaproic acid, the rates of cAMP generation were indistinguishable between control and experimental groups. In response to $20 \mathrm{mM}$ glucose and 3-isobutyl-1-methylxanthine (IBMX) (a phosphodiesterase inhibitor), cAMP generation in VE-infected islets was $81 \%$ (NS) of the control rate. When a more specific phosphodiesterase inhibitor, RO 20-1724, was used with $20 \mathrm{mM}$ glucose, cAMP generation in the infected islets was only $44 \%(P<0.001)$ of the control value. Insulin secretion over the perifusion period paralleled the CAMP levels. In the presence of $10 \mathrm{mM} \alpha$-ketoisocaproic acid, there was no difference in insulin secretion between VE-infected and control islets, while there was a statistically significant $(P<0.05)$ difference with $10 \mu \mathrm{M}$ glucagon or $20 \mathrm{mM}$ glucose (in $1 \mathrm{mM}$ RO 20-1724). These data point to a defect in the CAMP generation system of VE-infected islets, although additional factors involved in insulin secretion may also be impaired by the virus.
\end{abstract}

\section{Introduction}

A possible role of viruses in the pathogenesis of diabetes mellitus has been proposed since the mid-nineteenth century (1-3). Most of the studies performed in animal models of viral diabetes have used viruses highly lytic to beta cells in vivo, in which islet destruction parallels the degree of hyperglycemia $(4,5)$. We have found that inoculation of golden Syrian hamsters with Venezuelan encephalitis (VE) ${ }^{1}$ virus results in a sustained diminution

Portions of this work have been published in abstract form, 1983. Diabetes. 32(Suppl. 1):47a, No. 188; and were presented in part at the annual meeting of the American Diabetes Association, San Antonio, TX, 12 14 June 1983.

Address reprint requests to Dr. Rayfield. 1985.

Received for publication 27 July 1984 and in revised form 31 October

1. Abbreviations used in this paper: $\mathrm{B}$, rate of cyclic AMP generation cAMP, cyclic AMP; IBMX, 3-isobutyl-1-methylxanthine; RO 20-1724, d-4-(3-butoxy-4-methoxybenzyl)-2-imidazol-idinone; VE, Venezuelan encephalitis virus; $V_{\text {STD }}$, TC-83 vaccine strain of VE.

J. Clin. Invest.

(c) The American Society for Clinical Investigation, Inc.

0021-9738/86/03/0958/06 \$1.00

Volume 77, March 1986, 958-963 in glucose-stimulated insulin release, in vivo (6) and in vitro in isolated, perifused pancreatic islets of Langerhans (7). After VE infection, no long-term morphologic alterations in the pancreas are observed $(6,7)$. Specifically, there were no changes in islet volume density, volume density of individual islet subtypes (beta, alpha, delta, pancreatic polypeptide), or beta cell granulation in virus infected islets (7). Decreased insulin release can be corrected in vitro by 8-bromo-cyclic AMP (cAMP), dibutyryl cAMP, and by the phosphodiesterase inhibitor, theophylline (7). $\alpha$-Ketoisocaproic acid, an insulin secretagogue whose action is independent of glucose, induces normal insulin release in VE-infected islets (8). The finding that CAMP analogs and phosphodiesterase inhibitors can correct the virus-mediated diminution in insulin secretion suggested the importance of measuring the cAMP content in VE-infected and control islets in response to insulin secretagogues.

\section{Methods}

Animals and virus preparation. The LVG strain of golden Syrian hamsters (Charles River Breeding Laboratories, Wilmington, MA) weighing between 110 and $130 \mathrm{~g}$, were used in these studies. The animals were fed with hamster chow and water ad libidum until the time of study. Hamsters were inoculated with either $1 \times 10^{5}$ plaque-forming units of a plaquepurified variant of the TC-83 vaccine strain of VE $\left(\mathrm{VE}_{\mathrm{STD}}\right)$ virus in 0.2 ml of Hanks' balanced salt solution (Gibco, Grand Island, NY) adjusted

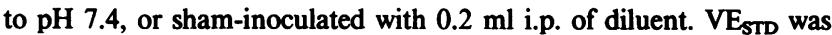
assayed by counting plaque-forming units on chicken embryonic cell monolayers under agar (9). Preinoculation and 21-d postinoculation acetone-extracted sera were measured for the presence of antiviral antibody by a microtiter hemagglutination-inhibition test (10) and only hamsters converting from negative titers to titers of $>\mathbf{4 0}$ were used in the studies. Glucose tolerance tests were performed with measurement of glucose and insulin levels preinoculation and $23 \mathrm{~d}$ after administration of virus as described previously (6).

Isolation of islets and perifusion techniques. Hamsters were anesthetized with $6.5 \mathrm{mg}$ of sodium pentobarbital (Abbott Diagnostics, North Chicago, IL). Islets of Langerhans were isolated from the pancreata of control and 24-d post-VE $\mathrm{VET}_{\text {ST }}$-virus inoculated hamsters by the collagenase (Worthington Diagnostics Div., Millipore Corp., Freehold, NJ) digestion method of Lacy and Kostianovsky (11), after which separation was achieved with a ficoll (Pharmacia Fine Chemicals, Piscataway, NJ) gradient. 25 islets from one infected hamster or one control hamster were used for each preparation with the number of preparations given by the number of points in each figure. The method of Zawalich et al. (12) was used for islet perifusion with one or more control and experimental chambers run in parallel in each experiment. The basal perifusion medium consisted of $115 \mathrm{mM} \mathrm{NaCl}, 5 \mathrm{mM} \mathrm{KCl}, 25 \mathrm{mM} \mathrm{NaHCO}, 1 \mathrm{mM}$ $\mathrm{MgCl}_{2}, 2.2 \mathrm{mM} \mathrm{CaCl}_{2}$, and $0.17 \%$ (insulin-free) bovine serum albumin, pH 7.4, that was gassed continuously with a mixture of $95 \% \mathrm{O}_{2}$ and $5 \%$ $\mathrm{CO}_{2}$. A flow rate of $1 \mathrm{ml} / \mathrm{min}$ was used in all perifusion studies. Islets were allowed to equilibrate at $37^{\circ} \mathrm{C}$ with $3 \mathrm{mM}$ glucose in the perifusion buffer for $60 \mathrm{~min}$ before the addition of the test agent. Samples of the perifusate were collected every $5 \mathrm{~min}$ for immunoreactive insulin and cAMP measurement. After $0,5,10,20$, or 40 -min exposure to the test agent ( $20 \mathrm{mM}$ glucose, glucagon, or $\alpha$-ketoisocaproic acid), the islets were immediately frozen in liquid nitrogen and stored at $-80^{\circ} \mathrm{C}$. Either 
1 mM 3-isobutyl-1-methyl-xanthine (IBMX; Sigma Chemical Co., St. Louis, MO) or $1 \mathrm{mM} d$-4-(3-butoxy-4-methoxybenzyl)-2-imidazolidinone (RO 20-1724; Hoffman-LaRoche, Inc., Nutley, NJ) as indicated, was added to the perifusion buffer (after equilibration) to retard the degradation of endogenous cAMP, which has a short $t^{1 / 2}$ ranging from 2.3 to $<1 \mathrm{~min}$ (13). Insulin was measured by a double antibody radioimmunoassay (14) with human insulin (Eli Lilly and Co., Indianapolis, IN) as standard.

In the perifusion protocols, the $\alpha$-ketoisocaproic acid was obtained from Sigma Chemical Co., and the glucagon was obtained from Dr. Mary Root, Eli Lilly and Co. Since the action of $\alpha$-ketoisocaproic acid is independent of glucose, a 15-min period of perifusion with glucosefree medium preceded all additions of $\alpha$-ketoisocaproic acid.

Islet DNA analysis. DNA content of the 25 islets in each chamber was determined by a very sensitive fluorimetric method using diaminobenzoic acid (Aldrich Chemical Co., Inc., Milwaukee, WI) (15). Insulin and other proteins were extracted first with acid-ethanol, and then the insoluble material was further purified using ethanol and ether before DNA assay. All insulin and cAMP levels were corrected for DNA content to adjust for any differences in size between control and VE-infected islets.

CAMP assay. The CAMP was extracted from the islets by a $16-\mathrm{h}$ incubation with $15 \%(\mathrm{wt} / \mathrm{wt}) \mathrm{TCA}$ at $4^{\circ} \mathrm{C}$. The TCA was removed by water-saturated ether extraction. Samples were lyophilized and cAMP content was measured by a sensitive double antibody radioimmunoassay modified from that of Zawalich et al. (16). Purified cAMP (Sigma Chemical Co.) was used as standard. The anti-acetyl cAMP antibody (prepared in rabbits) was purchased from New England Nuclear, Boston, MA. ${ }^{125}$ IcAMP was obtained from Dr. George Vanderhoff, University of Virginia School of Medicine, and the second antibody (goat anti-rabbit IgG) was obtained from Arnel Co, Brooklyn, NY. cAMP standards and samples were acetylated to yield 2'-O-acetyl cAMP in order to increase the sensitivity of the assay to the femtomole range (17).

Analysis of data. The rate of cAMP generation (B) and the regression lines were calculated by the method of least squares (17). This rate represents the net effect of production and degradation of cAMP, which reflects a multiplicity of factors. Differences between mean total insulin secretion of control and VE-infected islets were analyzed for significance using Student's $t$ test for unpaired variates. The variance of the insulin data is expressed as SEM. Correlation coefficients were calculated (18).

\section{Results}

Glucose tolerance tests. $23 \mathrm{~d}$ after inoculation with $\mathrm{VE}_{\mathrm{STD}}$ virus, all hamsters were glucose-intolerant (mean 60 min glucose $=460 \pm 10 \mathrm{mg} / \mathrm{dl}$ infected vs. mean $60 \mathrm{~min}$ glucose $=350 \pm 8$ $\mathrm{mg} / \mathrm{dl}$ control, $P<0.01$ ). VE $\mathrm{ETD}_{\text {STD }}$ virus-infected hamsters displayed decreased insulin levels after intraperitoneal glucose injection (mean $60 \mathrm{~min}$ insulin $=40 \pm 4 \mu \mathrm{U} / \mathrm{ml}$ infected vs. mean $60 \mathrm{~min}$ insulin $=138 \pm 7 \mu \mathrm{U} / \mathrm{ml}$ control, $P<0.01$ ).

Effect of glucose on islet cAMP generation. In the absence of a phosphodiesterase inhibitor, control (uninfected) islet cAMP content at time 0 with $3 \mathrm{mM}$ glucose was $0.30 \pm 0.02 \mathrm{pmol} / \mu \mathrm{g}$ islet DNA, whereas VE-infected islet cAMP content was $0.16 \pm 0.02 \mathrm{pmol} / \mu \mathrm{g}$ islet DNA. This difference was statistically significant $(P<0.05)$. In the presence of each secretagogue, cAMP was undetectable in the perifusion buffer at all times.

Effect of $\alpha$-ketoisocaproic acid and IBMX on CAMP generation. $\alpha$-Ketoisocaproic acid (which cannot be metabolized to glucose) induces the same insulin release in perifused hamster control and VE $\mathrm{VE}_{\text {STD }}$ virus-infected islets (8). $\alpha$-Ketoisocaproic acid also increases the cAMP content of isolated rat islets (19).

Under basal conditions ( $3 \mathrm{mM}$ glucose in the perifusion buffer), the mean cAMP content of VE $\mathrm{VE}_{\mathrm{STD}}$ virus-infected islets $(0.14 \pm 0.02 \mathrm{pmol} / \mu \mathrm{g}$ islet DNA) is approximately half that of control islets $(0.27 \pm 0.02 \mathrm{pmol} / \mu \mathrm{g}$ islet DNA) $(P<0.001)$ (Fig. $1 A$ ). After a 20 -min perifusion with $10 \mathrm{mM} \alpha$-ketoisocaproic

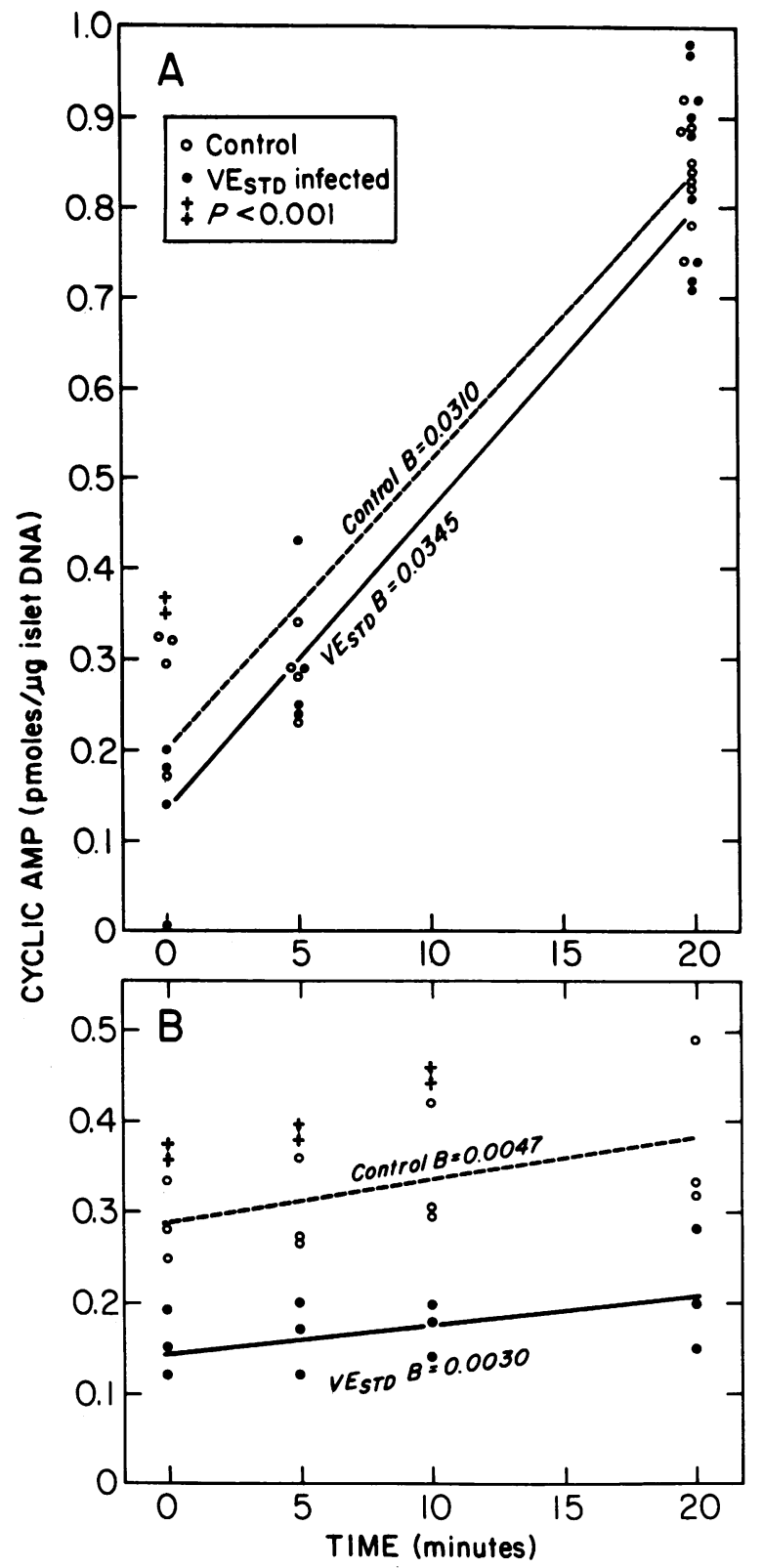

Figure 1. (A) The effect of $\alpha$-ketoisocaproic acid on cAMP content from VE-infected and control hamster islets. Each point represents the cAMP content of 25 islets isolated from the pancreata of control (0) or infected-24-d post VE inoculation (๑)-hamsters. The islets were perifused with $10 \mathrm{mM} \alpha$-ketoisocaproic acid and $1 \mathrm{mM}$ IBMX for the time period shown before the measurement of CAMP. B is the rate of cAMP generation. $(B)$ The effect of low glucose and IBMX on cAMP content from VE-infected and control hamster islets. The islets were perifused with $3 \mathrm{mM}$ glucose and $1 \mathrm{mM}$ IBMX for the time period shown before the measurement of cAMP.

acid and $1 \mathrm{mM}$ IBMX, mean cAMP content in control and VEinfected islets was indistinguishable. The rate of cAMP generation (B) was $0.0310 \mathrm{pmol} / \mu \mathrm{g}$ islet DNA per minute in control and $0.0345 \mathrm{pmol} / \mu \mathrm{g}$ islet DNA per minute in VE $\mathrm{VETD}_{\mathrm{ST}}$ virus-infected islets, respectively. This difference was not statistically significant.

Effect of glucose and IBMX on islet cAMP generation. In the presence of low ( $3 \mathrm{mM}$ ) glucose and IBMX the rate of cAMP generation was $0.0047 \mathrm{pmol} / \mu \mathrm{g}$ islet DNA per minute in control and $0.0030 \mathrm{pmol} / \mu \mathrm{g}$ islet DNA per minute in infected islets (Fig. 
$1 B$ ). This difference was not statistically significant although there was a tendency for cAMP content to increase during the 20-min perifusion.

Effect of glucagon, IBMX, and glucose on cAMP generation. Glucagon stimulates adenylate cyclase (20) and increases the cAMP content (21) of rat islets in vitro. Glucagon stimulates insulin release in vivo (22) and in the perfused rat pancreas (23). Basal cAMP content (with $3 \mathrm{mM}$ glucose and $1 \mathrm{mM}$ IBMX) is lower in VE $\mathrm{VE}_{\text {STD }}$ virus infected than in control islets $(P<0.05)$ (Fig. 2). In response to $10 \mu \mathrm{M}$ glucagon, cAMP content is lower after 10, 20, and $40 \mathrm{~min}$ in the infected islets $(P<0.05)$. cAMP increased 8.5 -fold in control islets, but only 5.7-fold in VE-infected islets after $20 \mathrm{~min}(P<0.001)$. The rate of cAMP generation $\left(0.0329 \mathrm{pmol}\right.$ cAMP $/ \mu$ g islet DNA per minute) in VE $\mathrm{E}_{\text {STD }}$ infected islets is half that of control islets $(B=0.0664 \mathrm{pmol}$ cAMP $/ \mu$ g islet DNA per minute) $(P<0.001)$ during a 40 -mịn perifusion.

Effect of glucose and IBMX on cAMP generation. Based upon observations with isolated, perifused islets (7), we hypothesized that cAMP generation in $\mathrm{VE}_{\mathrm{STD}}$-infected islets would be impaired in response to $20 \mathrm{mM}$ (high) glucose. In the presence of $20 \mathrm{mM}$ glucose (and $1 \mathrm{mM}$ IBMX), the rate of cAMP generation in VEinfected islets was $81 \%$ (NS) that in control islets (Fig. 3). This may be due to masking of the glucose-mediated increase in cAMP content by activation of the adenosine receptor. In addition to suppressing phosphodiesterase, IBMX is an adenosine $\left(\mathrm{A}_{1}\right)$ receptor antagonist (24), and can thus alter cAMP generation in islets (25).

Effect of glucose and RO 20-1724 on cAMP generation. Experiments were conducted with the phosphodiesterase inhibitor,

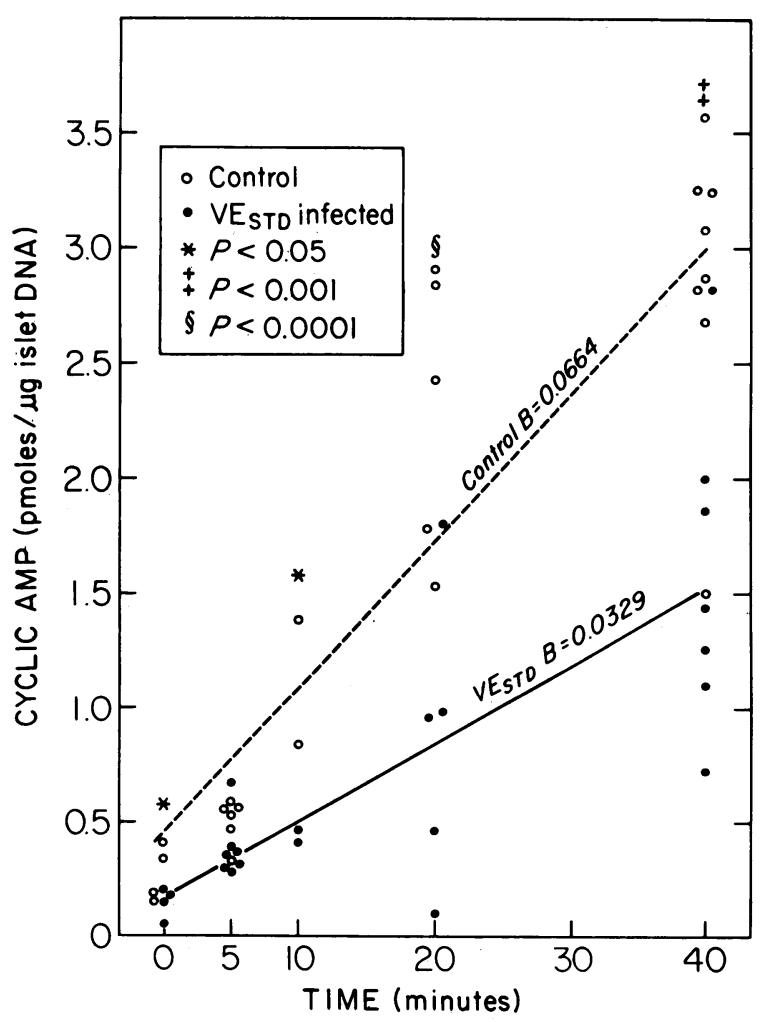

Figure 2. The effect of glucagon on cAMP content from VE-infected and control hamster islets. The islets were perifused with $10 \mu \mathrm{M}$ glucagon, $3 \mathrm{mM}$ glucose, and $1 \mathrm{mM}$ IBMX for the time period shown before the measurement of cAMP.

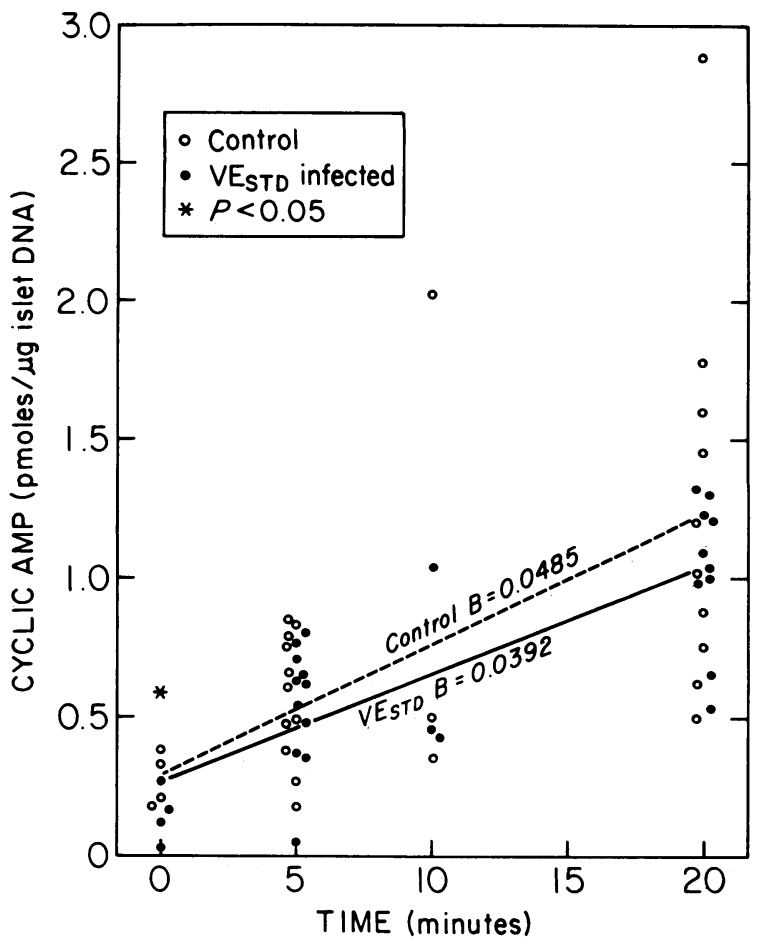

Figure 3. The effect of high glucose and IBMX on cAMP content from VE-infected and control hamster islets. The islets were perifused with $20 \mathrm{mM}$ glucose and $1 \mathrm{mM}$ IBMX for the time period shown before the measurement of cAMP.

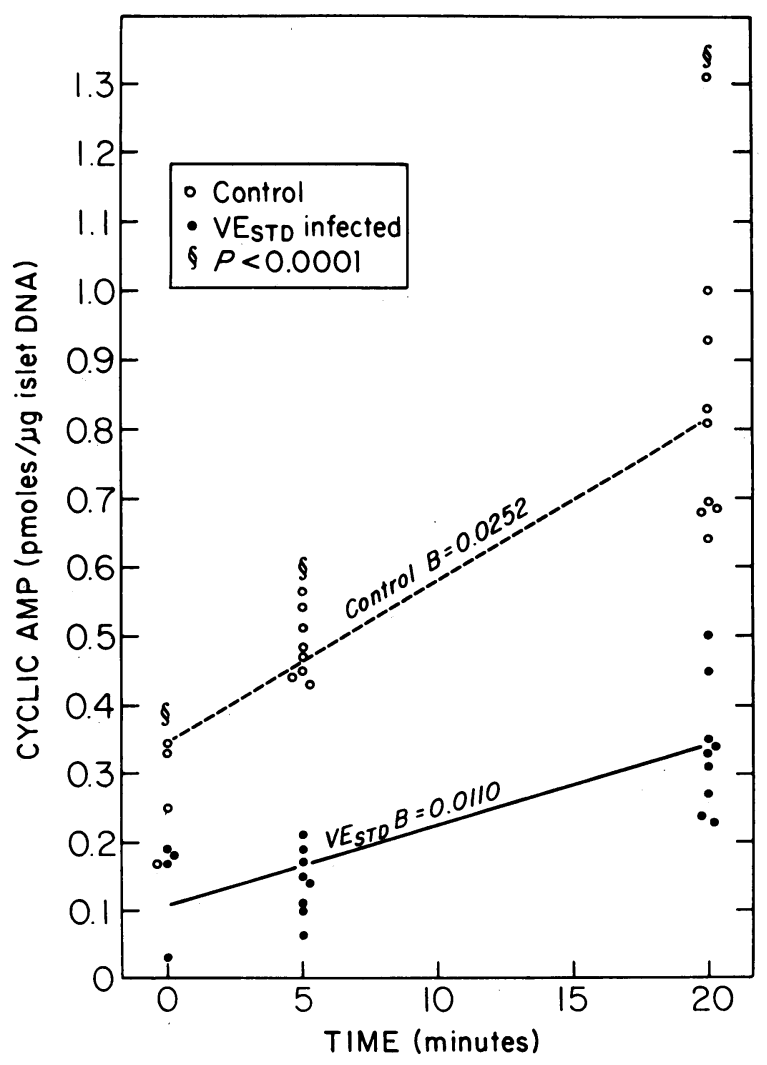

Figure 4. The effect of high glucose and RO 20-1724 on cAMP content from VE-infected and control hamster islets. The islets were perifused with $20 \mathrm{mM}$ glucose and $1 \mathrm{mM}$ RO 20-1724 for the time period shown before the measurement of CAMP. 
Table I. Correlation Coefficients between Insulin and cAMP Levels at 20 Min

\begin{tabular}{|c|c|c|c|c|c|c|}
\hline & $\begin{array}{l}3 \mathrm{mM} \text { glucose, } \\
\text { no IBMX }\end{array}$ & $\begin{array}{l}3 \mathrm{mM} \text { glucose, } \\
1 \mathrm{mM} \text { IBMX }\end{array}$ & $\begin{array}{l}10 \mathrm{mM} \alpha \text {-keto-isocaproic } \\
\text { acid, } 1 \mathrm{mM} \text { IBMX }\end{array}$ & $\begin{array}{l}10 \mu \mathrm{M} \text { glucagon, } \\
3 \mathrm{mM} \text { glucose, } \\
1 \mathrm{mM} \text { IBMX }\end{array}$ & $\begin{array}{l}20 \mathrm{mM} \text { glucose, } \\
1 \mathrm{mM} \text { IBMX }\end{array}$ & $\begin{array}{l}20 \mathrm{mM} \text { glucose, } \\
1 \mathrm{mM} \text { RO } \\
20-1724\end{array}$ \\
\hline Control & $0.96 \S(25)$ & $0.88 \S(12)$ & $0.95 \S(9)$ & $0.93 \ddagger(5)$ & $0.63^{*}(10)$ & $0.80 \ddagger(9)$ \\
\hline VE-infected & $0.96 \S(22)$ & $0.87 \S(12)$ & $0.86 \S(9)$ & $0.93 \ddagger(5)$ & $0.70^{*}(10)$ & $0.89 \S \quad(9)$ \\
\hline \multicolumn{7}{|l|}{ Combined } \\
\hline (Control and VE) & $0.96 \S(47)$ & $0.88 \S(24)$ & $0.90 \S(18)$ & $0.93 \S(10)$ & $0.65 \ddagger(20)$ & $0.811 \S(18)$ \\
\hline
\end{tabular}

* $P<0.05 ; \ddagger P<0.01 ; \S P<0.001$. Correlation coefficients for insulin and cAMP values were calculated after a 20-min perifusion with each secretagogue in control and VE-infected islets. The analysis was also carried out with the data from the two groups combined. Similar results were obtained at other time points. The numbers in parentheses represent the number of preparations ( 25 islets each) used to calculate the correlation coefficients.

RO 20-1724, which does not act through the adenosine receptor (26). After $20 \mathrm{~min}$ in the presence of $20 \mathrm{mM}$ glucose and $1 \mathrm{mM}$ RO 20-1724, the mean cAMP content of the VE $\mathrm{STD}_{\text {-infected }}$ islets was $40 \%$ of control (Fig. 4). This yielded a lower rate of cAMP generation (B) in infected $(0.0110 \mathrm{pmol} / \mu \mathrm{g}$ islet DNA per minute) than in control islets $(0.0252 \mathrm{pmol} / \mu \mathrm{g}$ islet DNA per minute) $(P<0.001)$. Thus, in the presence of a specific phosphodiesterase inhibitor, infected islets exhibit a significant (44\%) slowing in the generation of cAMP.

Effect of glucose, glucagon, $\alpha$-ketoisocaproic acid, IBMX, and RO 20-1724 on total insulin secretion from $V E_{S T D}$-infected and control hamsters. cAMP may serve as a second messenger for insulin release. Therefore, insulin secretion in VE-infected islets was correlated with cAMP production. Insulin and cAMP levels closely correlate $(P<0.05)$ in control and VE-infected islets as well as when the two are combined before analysis (Table I). There is no difference in response to $10 \mathrm{mM} \alpha$-ketoisocaproic acid or $20 \mathrm{mM}$ glucose (and $1 \mathrm{mM}$ IBMX) in insulin secretion between control and VE-infected islets (paralleling the absence of a difference in cAMP content) (Figs. 1, 3, and 5). In contrast, in the presence of $10 \mu \mathrm{M}$ glucagon and $3 \mathrm{mM}$ glucose (and 1 mM IBMX), there is a significant $(P<0.05)$ difference between mean total insulin secretion for control and VE-infected islets. Mean total insulin secretion in control and VE-infected islets was also different $(P<0.05)$ with $20 \mathrm{mM}$ glucose and $1 \mathrm{mM}$ RO 20-1724 (Fig. 5). cAMP generation and insulin secretion are closely linked with these secretagogues. The finding that absolute levels of CAMP do not always predict the corresponding insulin levels suggests that factors other than the cAMP generating system of the beta cell are modified by viral infection. Such factors could include calmodulin and calcium-sensitive enzymes (27).

\section{Discussion}

Viral agents, autoimmunity, chemicals, and toxins may contribute singly or in combination to the pathogenesis of diabetes mellitus (28-30). We developed a hamster model in which VE virus infection results in a significant diminution of glucosestimulated insulin release in vivo and vitro $(6,7)$. Since VE virus is relatively non-lytic, no long-term morphologic nor morphometric changes are demonstrable in the islets from infected hamsters $(6,7)$. The decrease in insulin release triggered by glucose can be corrected in vitro in isolated perifused islets treated with agents that raise cAMP levels: theophylline (a phosphodiesterase inhibitor) and cAMP analogs (7).

The virus-induced defect in insulin release does not result from a nonspecific membrane effect. Thus, when VE-infected and control islets are perifused with $\alpha$-ketoisocaproic acid in the absence of glucose, no difference is observed in insulin release in the two groups (8). $\alpha$-Ketoisocaproic acid, a metabolite of leucine that is ketogenic, stimulates insulin secretion in vivo and in vitro, and islet cAMP content $(8,19,31)$. The decrease in insulin secretion is also correctable with tolbutamide (7), and resembles the clinical picture found in noninsulin-dependent diabetes mellitus (30).

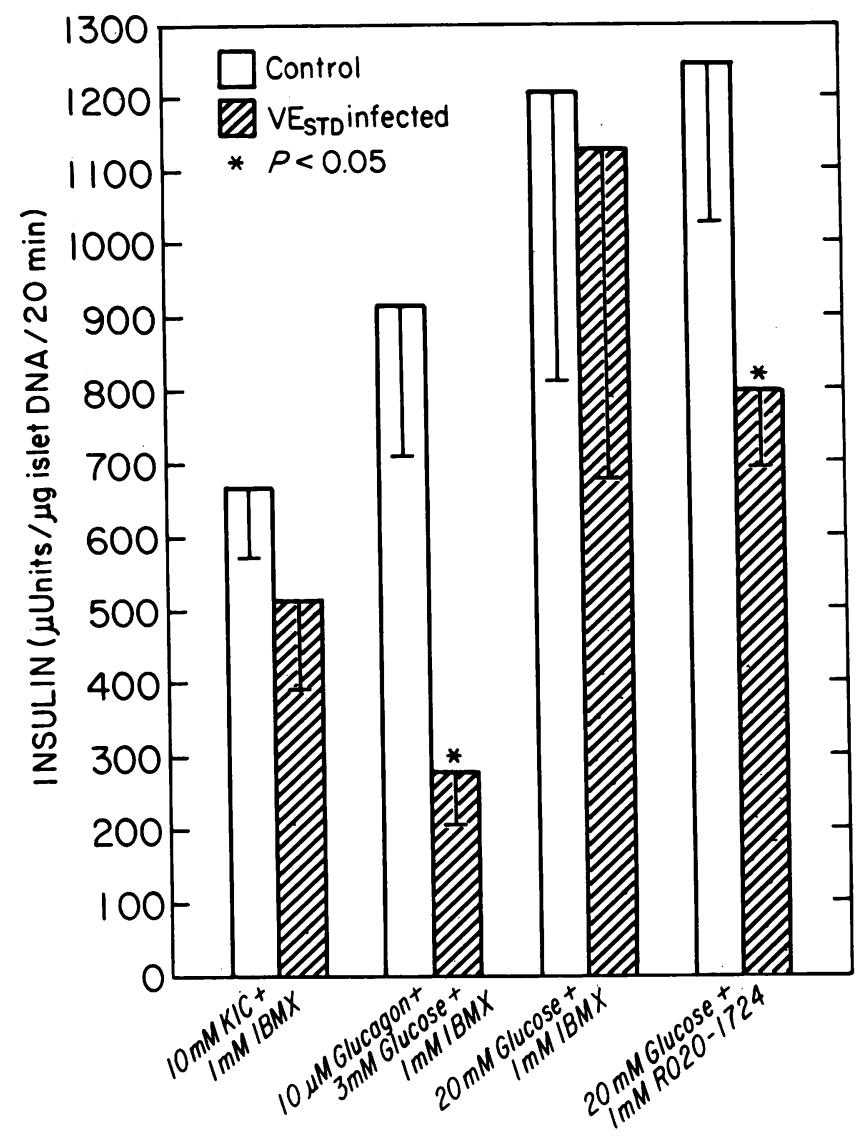

Figure 5. The effect of $\alpha$-ketoisocaproic acid, glucagon, glucose, IBMX, and RO-1724 on total insulin secretion from VE-infected and control hamsters. The bars represent the mean total insulin released by 25 islets isolated from the pancreata of control (open bars) or infected-24-d post VE inoculation (lined bar)-hamsters in a 20-min perifusion period. The lines within the bars represent the SEM. 
In the present study, changes of intracellular cAMP content of islets were measured over time in response to insulin secretagogues to assess the locus at which VE virus interacts with the adenylate cyclase system of the beta cell. In the presence of 10 $\mu \mathrm{M}$ glucagon (which depends on glucose for its ability to stimulate insulin release), the rate of generation of cAMP in islets from VE-infected hamsters is half that of control islets (Fig. 2) $(P<0.001)$. In islets exposed to $\alpha$-ketoisocaproic acid (which acts independently of glucose to induce insulin release), the rates in control and virus infected groups are indistinguishable (Fig. $1 A$ ). cAMP is rapidly degraded in cells to $5^{\prime}$ AMP by one or more phosphodiesterases $(13,32)$. This necessitated the use of a phosphodiesterase inhibitor in the perifusion system to obtain meaningful values of islet cAMP content. However, IBMX affects the adenosine receptor, which modulates adenylate cyclase activity (25). With IBMX, there was no difference in the rate of generation of cAMP in control and VE-infected islets in the presence of $20 \mathrm{mM}$ glucose. However, when RO 20-1724, which does not affect the adenosine receptor (26), was used, the generation of cAMP in VE-infected islets was $44 \%$ of the control value (Fig. 4). These results could be explained if IBMX were more inhibitory to phosphodiesterase and VE-infected islets had a greater concentration of phosphodiesterase.

Although there is a significant difference $(P<0.05)$ in basal cAMP levels in control and VE islets (Figs. 1-4), the importance of this difference is not established. $\alpha$-Ketoisocaproic acid stimulated cAMP generation in VE-infected islets overcomes the decreased basal levels in contrast to glucose and glucagon, which exaggerate the diminution in CAMP production. This difference in basal cAMP content is glucose-dependent since the basal medium contains $3 \mathrm{mM}$ glucose.

Many agents that stimulate insulin release, such as glucose (33), glucagon $(21,22)$, tolbutamide (33), and $\alpha$-ketoisocaproic acid (19), also increase islet cAMP content. The binding of various ligands to receptors in the plasmalemma of cells activates adenylate cyclase, which converts ATP to cAMP (34). cAMP has been established as a "second messenger" in the regulation of various intracellular processes (34). This begins a cascade of phosphorylation reactions which activate and inactivate enzymes regulating insulin secretion (35).

Accordingly, insulin secretion in $\mathrm{VE}_{\mathrm{STD}}$ infected and control islets was compared with cAMP generation (Table I). With each secretagogue, cAMP content and insulin secretion were significantly $(P<0.05)$ correlated. However, a causal relationship between cAMP elevation and insulin secretion is not established in this study. Other mechanisms must be operative since cAMP levels do not completely predict insulin levels. For example, production of the same cAMP level by various secretagogues does not result in the same insulin secretion. Many factors, in addition to cAMP, are important in determining insulin secretion. Each factor may have a different relative influence with a specific secretagogue (27) (36). In islets from infected hamsters perifused with $10 \mu \mathrm{M}$ glucagon (in $3 \mathrm{mM}$ glucose, $1 \mathrm{mM}$ IBMX) or $20 \mathrm{mM}$ glucose (in $1 \mathrm{mM}$ RO 20-1724), insulin secretion was significantly $(P<0.05)$ decreased, corresponding to a similar decrease in cAMP production. In contrast, insulin secretion did not differ significantly in the control and infected islets in experiments using $10 \mathrm{mM} \alpha$-ketoisocaproic acid (in $1 \mathrm{mM}$ IBMX) or $20 \mathrm{mM}$ glucose (in $1 \mathrm{mM}$ IBMX). Again, insulin secretion closely mirrored islet cAMP generation, which was also not significantly different between $\mathrm{VE}_{\mathrm{STD}}$-infected and control islets. Our data are consistent with a complex view of the VE virus- induced defect in glucose-stimulated insulin secretion. This defect may be mediated by a number of factors, including one in the adenylate cyclase-cAMP system of the islet. The lower insulin response could also involve other factors such as virus-induced abnormalities in calmodulin or calcium-sensitive enzymes (27).

Glucagon and glucose or glucose (in the presence of a specific phosphodiesterase inhibitor) elicit lower cAMP levels and insulin response in islets from hamsters infected with $\mathrm{VE}_{\mathrm{STD}}$ virus. This could result from alteration in the adenylate cyclase system, as well as from non-cAMP-dependent mechanisms. The normal cAMP generation in $\mathrm{VE}_{\text {STD }}$ virus-infected islets induced by $\alpha-$ ketoisocaproic acid suggests that there may be specificity to this defect. VE virus replicates in hamster pancreas (6) and its proteins are incorporated into the host cell's membrane during budding (37). Thus, viral proteins could change the activity of adenylate cyclase as well as act on non-cAMP factors involved in the regulation of insulin secretion.

\section{Acknowledgments}

We are indebted to Dr. Thomas Mittag and Dr. Walter Zawalich for valuable discussions, to Scott Plevy for skilled technical assistance, to Dr. W. E. Scott for providing compound RO 20-1724, and to Richard Hyfler of Arnel Co., New York, NY, for bovine serum albumin and goat anti-rabbit IgG antibody.

This work was supported in part by grants from the Kroc Foundation; the Juvenile Diabetes Foundation; the American Diabetes Association, New York Diabetes Affiliate; and a donation in honor of Dr. Gerald J. Friedman.

\section{References}

1. Craighead, J. E. 1975. The role of viruses in the pathogenesis of pancreatic disease and diabetes mellitus. Prog. Med. Virol. 19:162-214.

2. Notkins, A. L., J. W. Yoon, T. Onodera, A. Toniolo, and A. B. Jenson. 1981. Virus-induced diabetes mellitus. In Prospectives in Virology. XI. M. Pollard, editor. Alan R. Liss, Inc., New York. 141-162.

3. Rayfield, E. J., and Y. Seto. 1978. Viruses and the pathogenesis of diabetes mellitus. Diabetes. 27:1126-1142.

4. Hayashi, K., D. W. Boucher, and A. L. Notkins. 1974. Virusinduced diabetes. II. Relationship between beta cell damage and hyperglycemia in mice infected with encephalomyocarditis virus. Am. J. Pathol. 17:91-95.

5. Yoon, J. W., T. Onodera, and A. L. Notkins. 1978. Virus-induced diabetes mellitus. XV. Beta cell damage and insulin-dependent hyperglycemia in mice infected with coxsackie virus $B_{4}$. J. Exp. Med. 148: 1068-1080.

6. Rayfield, E. J., L. Gorelkin, R. T. Curnow, and P. B. Jahrling. 1976. Virus-induced pancreatic disease by Venezuelan encephalitis virus. Alterations in glucose tolerance and insulin release. Diabetes. 25:623631.

7. Rayfield, E. J., Y. Seto, S. Walsh, and R. C. McEvoy. 1981. Virusinduced alterations in insulin release in hamster islets of Langerhans. $J$. Clin. Invest. 68:1172-1181.

8. Rayfield, E. J., K. J. Kelly, and J. C. Thornton. 1983: Viral infection alters cAMP generation. Diabetes. 32(Suppl. 1):47A. (Abstr.)

9. Jahrling, P. B., E. Dendy, and G. A. Eddy. 1974. Correlates to increased lethality of attenuated Venezuelan encephalitis vaccine for immunosuppressed hamsters. Infect. Immun. 9:924-930.

10. Clarke, D. H., and J. Casals. 1958. Techniques for hemagglutination and hemagglutination-inhibition with arthropod-borne viruses. Am. J. Trop. Med. Hyg. 7:561-573.

11. Lacy, P. E., and M. Kostianovsky. 1967. Method for the isolation of intact islets of Langerhans from the rat pancreas. Diabetes. 16:35-39. 
12. Zawalich, W. S., A. S. Pagliara, and F. M. Matchinsky. 1977. Effect of iodoacetate, mannoheptulose and 3-0-methyl glucose on the secretory function and metabolism of isolated pancreatic islets. Endocrinology. 100:1276-1283.

13. Perkins, J. P., Y.-F. Su, G. L. Johnson, R. Ortmann, and B. H. Leichtling. 1976. Methods for the study of cyclic AMP metabolism in intact cells. In Eukaryotic Cell Function and Growth: Regulation by Intracellular Cyclic Nucleotides. J. E. Dumont, B. L. Brown, and N. J. Marshall, editors. Plenum Press, New York and London. 313-331.

14. Juan, C., and T. W. AvRuskin. 1971. Combined immunoassay of human growth hormone and insulin. Cumulative assessment of assay performance. J. Clin. Endocrinol. Metab. 33:150-152.

15. Hinegardner, R. T. 1971. An improved fluorimetric assay for DNA. Anal. Biochem. 39:197-201.

16. Zawalich, W. S., R. C. Karl, J. A. Ferrendelli, and F. M. Matschinsky. 1975. Factors governing glucose induced elevation of cyclic 3'5' AMP levels in pancreatic islets. Diabetologia. 11:231-235.

17. Harper, J. F., and G. Brooker. 1975. Femtomole sensitive radioimmunoassay for cyclic AMP and cyclic GMP after 2'O acetylation by acetic anhydride in aqueous solution. J. Cyclic Nucleotide Res. 1: 207-218.

18. Sokal, R. R., and F. J. Rohef. 1973. Introduction to Biostatistics, W. H. Freeman and Co., San Francisco. 261-285.

19. Shauder, P., C. McIntosh, B. Schindler, V. Panten, and H. Frerichs. 1978. Comparison of $\alpha$-ketoisocaproate and glucose in rats. Effects of insulin and somatostatin release and on islet cAMP content. Mol. Cell. Endocr. 11:51-61.

20. Goldfine, I. D., J. Roth, and L. Birnbaumer. 1972. Glucagon receptors in beta cells. J. Biol. Chem. 247:1211-1218.

21. Turtle, J. R., and D. M. Kipnis. 1967. An adrenergic receptor mechanism for the control of cyclic $3^{\prime} 5^{\prime}$ adenosine monophosphate synthesis in tissues. Biochem. Biophys. Res. Commun. 28:797-802.

22. Samols, E., G. Marri, and V. Marks. 1965. Promotion of insulin secretion by glucagon. Lancet. II:415-416.

23. Curry, DL. 1970. Glucagon potentiation of insulin secretion by the perfused rat pancreas. Diabetes. 19:420-428.

24. Daly, J. W. 1982. Adenosine receptors. Targets for future drugs. J. Med. Chem. 25:197-207.

25. Katada, T., and M. Ui. 1982. Islet-activating protein. A modifier of receptor-mediated regulation of rat adenylate cyclase. J. Biol. Chem. 256:8310-8317.

26. Londos, C., P. M. F. Cooper, W. Schlegel, and M. Rodbell. 1978. Adenosine analogs inhibit adipocyte adenylate cyclase by a GTP-dependent process. Basis for actions of adenosine and methylxanthines on cyclic AMP production and lipolysis. Proc. Natl. Acad. Sci. USA. 75(11): 5362-5366.

27. Montague, W. 1983. Insulin synthesis, storage, and secretion. In Diabetes and the Endocrine Pancreas: A Biochemical Approach. Oxford University Press, New York. 2:27-60.

28. Toniolo, A., T. Onodera, J. W. Yoon, and A. L. Notkins. 1980. Induction of diabetes by cumulative environmental insults from viruses and chemicals. Nature (Lond.). 288:383-385.

29. Craighead, J. E. 1978. Current views on the etiology of insulindependent diabetes mellitus. $N$. Engl. J. Med. 299:1439-1445.

30. Rayfield, E. J., and S. J. Mento. 1983. Hypothesis. Viruses may be etiologic agents for non-insulin dependent (type II) diabetes. Rev. Infect. Dis. 5:341-345.

31. Goedde, H. W., and W. Keller. 1967. Metabolic pathways in maple syrup disease. In Amino Acid Metabolism and Genetic Variation. W. L. Nyhan, editor. McGraw Hill Book Co., New York. 191-214.

32. Stefanovich, V. 1978. Cyclic nucleotide phosphodiesterase inhibitors as potential therapeutic agents. In Cyclic Nucleotides and Therapeutic Perspectives. G. Cehovic and G. A. Robinson, editors. Pergamon Press, Oxford. 147-163.

33. Charles, M. A., J. Lawecki, A. L. Steiner, and G. M. Grodsky. 1976. Cyclic nucleotides in pancreatic islets. Tolbutamide and arginineinduced insulin release. Diabetes. 25:256-259.

34. Sutherland, E. W. 1972. Studies on the mechanism of hormone action. Science (Wash. DC). 177:401-408.

35. Shubart, U. K., J. Erlichman, and N. Fleischer. 1982. Regulation of insulin release and protein phosphorylation by calcium and cyclic AMP. Possible role for calmodulin. In Calcium and Cell Function, Vol. III. W. Y. Cheung, editor. Academic Press, Inc., New York. 381-407.

36. Christie, M. R., and S. J. H. Ashcroft. 1984. Cyclic AMP-dependent protein phosphorylation and insulin secretion in intact islets of Langerhans. Biochem. J. 218:87-99.

37. Horzinek, M. C. 1975. The structure of togaviruses and bunyaviruses. Med. Biol. (Helsinki). 53:406-411. 